\title{
Drug Substance Specification
}

National Cancer Institute

\section{Source}

National Cancer Institute. Drug Substance Specification. NCI Thesaurus. Code C134022.

The specification which is applied to the drug substance. 